\title{
Diagnóstico diferencial en defecto de repleción ureteral
}

\author{
M. Allué López, P. Serrano Frago, D. Pascual Regueiro, A. García de Jalón Martínez \\ P. Gil Martínez, L.A. Rioja Sanz
}

Servicio se Urología. Hospital Universitario Miguel Servet. Zaragoza.

Actas Urol Esp 2005; 29 (2): 240

$\mathrm{V}$

arón de 42 años que acude a urgencias ante dolor lumbar derecho, fiebre y hematuria. Se realiza derivación urinaria mediante nefrostomía percutánea. La imagen radiológica muestra un defecto de replección ureteral derecho que plantea el diagnóstico diferencial entre coágulo en vía urinaria, litiasis ureteral radiotrasparente de morfología inusual o tumor ureteral. La realización de ureteroscopia reveló la presencia de litiasis alargada de gran tamaño formando un molde ureteral. Se fragmentó con Lithoclast ${ }^{\circledR}$ extrayéndose seguidamente los fragmentos.

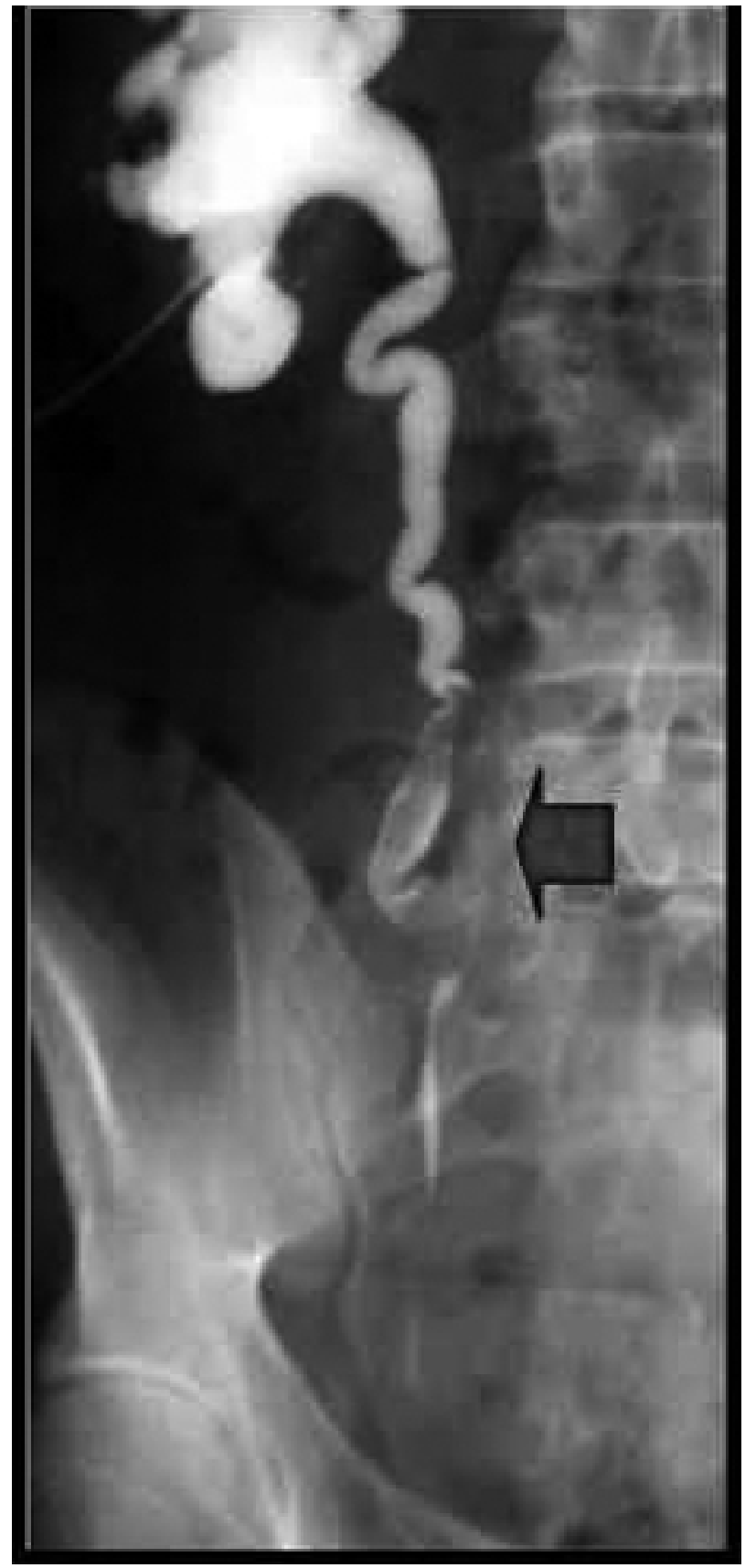

